\title{
Strategies for Improving Quantity Surveyors' Education Training in Uganda
}

\author{
Nathan Kibwami ${ }^{1}$, Racheal Wesonga ${ }^{1}$, Musa Manga ${ }^{1} \&$ Tom Mukasa $^{2}$ \\ ${ }^{1}$ Department of Construction Economics and Management, Makerere University, Kampala, Uganda \\ ${ }^{2}$ Pearl Engineering Company Limited, Kampala, Uganda \\ Correspondence: Nathan Kibwami, Department of Construction Economics and Management, Makerere \\ University, P.O. Box 7062, Kampala, Uganda. E-mail: knathan@cedat.mak.ac.ug
}

Received: July 28, $2020 \quad$ Accepted: October 8, $2020 \quad$ Online Published: January 25, 2021

doi:10.5539/ies.v14n2p33 URL: https://doi.org/10.5539/ies.v14n2p33

\begin{abstract}
Education and training of Quantity Surveyors (QSs) has been a topical subject amongst academics, the industry, and professional institutions, often leading to a discussion about education versus training, in which case, the industry sometimes argues that QSs are often ill-prepared for work. The current study investigated strategies for improving QSs' education training in Uganda, with a focus on devising ways of engendering better graduates that are fit for the industry. A semi-structured online questionnaire was used to collect data. The research population included QSs practicing in the Ugandan Construction Industry. The majority of respondents agreed to a great extent that QSs, and thus their training, are still relevant in the current construction industry. Majority of respondents desired the teaching curriculum to include more practical aspects that expose students to real challenges in practice. It was suggested that early exposure of students to real field practice was paramount to students' training. Engagements such as industrial training and internship placements in Quantity Surveying firms were highly encouraged. The curriculum also needs to be responsive to recent advances in industry practices, such as Building Information Modelling (BIM). Meanwhile, the University should intensify action research with the industry, and forge collaborations with all the key players in the construction sector to streamline the training. The findings of this study, if implemented, could potentially improve the quality of Quantity Surveying programmes at institutions of higher learning in similar developing countries. This would hopefully produce graduates who are industrially relevant and with a sound academic background.
\end{abstract}

Keywords: building economics, construction management, education, quantity surveying, Uganda

\section{Introduction}

In most countries around the world, the production of construction products takes place within an all-important industry, the construction industry. Although this industry is complex, since it covers a wide range of loosely integrated groups of participants and sub-markets, it is responsible for the procurement of investment products that contribute to the well-being and functioning of a modern national economy (Kwakye, 1997). Part of the complex organization structure of the construction industry, are the professionals who offer design and management services for a fee, and within the sub-categories of these professionals are the Quantity Surveyors. A Quantity Surveyor (QS), who is typically responsible for the study of the economics and financial implications of a construction project, has traditionally been known to ensure that a project is kept within the agreed budget and that the employer/client obtains value for money (Seeley, 1997). Kirkham (2015) further explains that QSs are therefore broadly concerned with the commercial management of construction projects.

The education and training needs of QSs have been a topical subject, notably, by three key stakeholders: academics, the industry, professional institutions. This tripartite three directional pull on the development needs of the QS is often unrecognized by the education systems, leading to many problems including fueling the "education versus training" debate and conflict between educators and employers. The conflict and a lack of alignment of industry, academic, and professional perspectives create a barrier to the development of the profession as well as the career development of the graduate QS (RICS, 2011). Perera (2006) takes note of the existing trend where a majority of new Quantity Surveying graduates are finding work more in non-traditional Quantity Surveying routes, such as main contracting and specialized subcontracting organisations, as opposed to private consulting practices and the public sector. However, much of the academic content being taught is usually directed to more 
traditional roles, another identified failure by all parties, to appreciate the dynamics of the construction industry market sector (RICS, 2011; Perera, Pearson, Robson, \& Ekundayo, 2011).

It has therefore been suggested that the present education system of Quantity Surveying does not recognize the multi-directional needs of the QS, hence the production of graduates whom the industry sees as not fulfilling their requirements. As such, it is important to understand, from the industry perspective, the perceptions regarding strategies that can be used to improve the Quantity Surveying training curriculum, such that the needs of the various stakeholders can be addressed in tandem. This study addresses this gap by investigating the strategies that can be used to improve Quantity Surveying training curriculum, focusing on the perceptions from QSs in the construction industry of Uganda.

\section{The Quantity Surveying Profession}

\subsection{Key Traditional and Evolving Roles of the Quantity Surveyor}

The Professional Quantity Surveyor (PQS) has been in existence mainly as a client's cost consultant and cost manager typically under two main stages of the construction process: offering pre-contract and post-contract cost advice, prior to and after the selection of a contractor for executing the project work, respectively (Towey, 2012). Ashworth, Hogg, and Higgs (2013) identify the following traditional roles of a QS: Single rate approximate estimates; Cost planning; Procurement advice; Measurement and quantification; Document preparation, especially bills of quantities; Cost control during construction; Interim valuations and payments; Financial statement; Final account preparation and agreement; and Settlement of contractual claims. The preceding roles, which had put the QS at the centre of measurement and production of Bills of Quantities for construction works, have been gradually expanded and transformed into a series of additional services as a result of multiple factors which have been well documented by a number of scholars (see Cartlidge, 2011; Towey, 2012; and Ashworth, Hogg, \& Higgs, 2013).

Several factors have been attributed to the evolving role of QSs, and the services they offer to their clients. Cartlidge (2011) offers a few insights including: information technology revolution; demand by clients for demonstrated added value; blurring of the distinction between contracting and professional service organisations; emergence of large private clients under privatization schemes and public-private partnerships (PPPs); and the introduction of fee competition between professional practices as opposed to strict adherence to published scales of fees. The practice and procedure for the QS has therefore been diversified from the production of Bills of Quantities and final accounts, to a much wider range of activities and sectors. Cartlidge (2011) identifies development management, project monitoring, employer's agent, and disaster management as part of the new aspects of Quantity Surveying practice. Ashworth, Hogg, and Higgs (2013) mention about 20 evolved roles of Quantity Surveying work, as summarized in Table 1.

Table 1. Evolved role of quantity surveying work

\begin{tabular}{llll}
\hline 1. & Investment appraisal & 11. & Planning and supervision \\
2. & Advice on cost limits and budgets & 12. & Valuation for insurance purposes \\
3. & Whole life costing & 13. & Facilities management \\
4. & Value management & 14. & Administering maintenance programmes \\
5. & Risk analysis & 15. & Advice on contractual disputes \\
6. & Insolvency services & 16. & Planning supervisor \\
7. & Cost engineering services & 17. & Employer's agent \\
8. & Subcontract administration & 18. & Programme management \\
9. & Environmental services measurement and costing & 19. & Cost modeling \\
10. & Technical auditing & 20. & Sustainability advisor \\
\hline
\end{tabular}

Source: Adapted from Ashworth, Hogg, and Higgs (2013)

Alongside the development of the traditional PQS, emerged the contractor's Quantity Surveyor (CQS), undertaking an increasingly important role with contracting organisations. Seeley (1997) notes that by 1990, 19\% of all chartered QSs were employed by contractors. As far back as 1974, many of the chartered QSs in the construction industry were either directors or managers of large departments. These chattered QSs were undertaking a range of services broader than traditional estimating, measurement, and settlement of final accounts, with approximately $40 \%$ holding director appointments by 1978 . With a common base involving measurement, valuation and financial reporting, other duties of a CQS include involvement in estimating and bid management, buying, calculating bonus incentive schemes, scheduling and monitoring materials and other resources, making 
inquiries and placing orders with suppliers and subcontractors, debtor control, site costing and plant control. Such processes and procedures have come to be broadly referred to as commercial management of construction (RICS, 2016a).

There is evidence that QSs and their firms made concerted efforts to improve their entrepreneurial capabilities through various forms of innovation such as service product, process, market, organizational and resource innovation (Schumpeter, 1983). Progressively, these innovations have registered the following positive impacts: reducing costs; expanding fee income; improving profit margins; improving quality of services; extending range of services, enhancing ability to adapt; bringing new clients to firms; and enhancing the reputation of QSs (RICS, 2004).

\subsection{The Key Skills and Competencies of Quantity Surveyors}

Although there may be a general lack of an over-arching global standard regarding competencies of QSs, there are common themes which have been set up through the leading institutions such as the International Federation of Surveyors (FIG), Royal Institution of Chartered Surveyors (RICS) and Australian Institute of Quantity Surveyors (AIQS). For example, RICS competencies for the Quantity Surveying and Construction pathway, are arranged into three sections - Mandatory, Core, and Optional competencies. In addition, there are three possible levels of attainment for each competence - Level 1, Level 2, and Level 3. Level 1 covers the theoretical knowledge; Level 2 covers the knowledge and practical experience; and Level 3 is about a combination of knowledge, practical experience, and capacity to advice. A similar arrangement has been adopted by the FIG Commission 10, which unites national associations for Quantity Surveying, construction economics, and cost engineering, globally. Meanwhile, AIQS (2012) covers a broad range of expertise provided by the modern QS, and extend beyond some of the more traditional Quantity Surveying services. These are categorized into: Basic skills, which need to be acquired during tertiary education and are part of the core competencies; Core competencies, which are the required skills of a competent QS; and Specialised competencies, which are the skills gained in areas akin to Quantity Surveying, but which may become primary business functions.

\subsection{Quantity Surveying Practice in Uganda}

Quantity surveying practice in Uganda dates back to the colonial era under the British protectorate and the present-day Institution of Surveyors of Uganda (ISU) was founded in 1968 as the Association of Surveyors of Uganda (ASU). This was mainly done by Land Surveyors under RICS general practice-chartered surveyors who were practicing in Uganda by then. Although there used to be the Architects and QSs Act 1954, it is believed to have been repealed in 1996 without the involvement of QSs practicing in Uganda at that time. In 1974, the association (ASU) would extend its coverage to accommodate Quantity Surveying and Valuation Surveying. This was under the Surveyors Registration Act 1974, after a decree redefined the "Surveyor" in the law to include "Quantity Surveying, Valuation Surveying, Building Surveying, Hydrological Surveying, Mining Surveying, Land Management and Agency". However, these additional specialisms were never expressly defined under the law to ensure their operationalization. In 1981, members changed the nomenclature from ASU to ISU, but this change of name was not entrenched in the law until 2012 after the Public Procurement and Disposal of Assets Authority of Uganda (PPDA) challenged the legal status of ISU in 2011. This challenge was overcome after registering ISU with Uganda Registration Services Bureau (URSB) in 2012 (ISU, 2019).

The ISU is currently the umbrella body for all surveying professionals in Uganda, and similar to other professional bodies, ISU exists to safeguard the public by contributing to the setting of surveying standards of competence for her members, enforcing a code of good conduct, improving the standing of members on the market, and maintaining and developing a collective body of knowledge, for the surveying profession at large. There are 3 main groupings of surveyors within ISU, arranged in three chapters for Valuation Surveying, Land Surveying, and Quantity Surveying. By March 2019, membership of ISU comprised 1,232 members (excluding student members) of which 625 (51\%) were Land Surveyors; 339 (27.5\%) were Valuation Surveyors; 265 (21.5\%) were QSs; and 3 $(0.2 \%)$ were Honorary members.

The management of the affairs and business of the institution is vested in the Council of ISU. Membership categories of ISU comprise Fellows, Professional Members, Associate Members, Graduates, Technicians, Students, and Honorary members. However, only Professional members and Fellows are legally recognized and certified to work as QSs in Uganda. To progress to the above categories, Graduate or other new members are required to prove their professional competencies through an Assessment of Professional Competence system similar to the RICSs', in order to prove their knowledge, practical experience, and advanced skills in key surveying practice. Upon admission to Associate membership, candidates are then eligible to apply for registration and certification by the Surveyors Registration Board of Uganda, subsequently becoming recognised professionals 
under the Surveyors Registration Act 1974. Progression to Fellowship is by professional members who are able to fulfill further requirements as set out in the constitution, by-laws, and policies of the institution.

By March 2019, membership of ISU QS Chapter comprised 265 members (excluding student members) of which 36 (13.6\%) were Fellows; 29 (10.9\%) were Professional members; 37 (14\%) were Associate members; 161 $(60.8 \%)$ were Graduate members, and only $2(0.8 \%)$ were Technician members. As such, a total of 65 (approximately 25\%) of the membership are legally allowed to practice Quantity Surveying in Uganda. However, a lot of Graduate members are hesitant to apply for higher levels of membership. It should be noted, that the current regulations allow each registered QS to work with a maximum of 10 assistants who can be any of the other members of the QS Chapter. This practically absorbs everyone on the current list of membership. What therefore needs to be investigated is the number of graduates from the Higher Institutions of learning who do not come forward to be recognized under the institution, but find employment in other sectors, including the highly lucrative informal construction sector, identified in several developing countries.

Published literature on the history of Quantity Surveying in Uganda is scarce. Anecdotal evidence suggests that the first post-independence QS practices in Uganda were incorporated by graduates from Britain, who had also had their initial training in Kenya and Tanzania from the University of Nairobi and Ardhi Institute (later University College of Lands and Architectural Studies under the University of Dar es Salaam, and currently Ardhi University) respectively. In Tanzania, Building Design and Building Economics training programmes started in 1976 and 1978 respectively and in 1996 Ardhi Institute was affiliated with the University of Dar es Salaam and became a Constituent College of the University of Dar es Salaam, namely the University College of Lands and Architectural Studies (UCLAS). In Kenya, the College of Architecture and Engineering (CAE) is one of the six colleges of the University of Nairobi, which together with the other five colleges was established in the year 1984. However, the history of CAE can be traced back to 1956 when it started as the Royal Technical College, which used to admit students from the whole of the East African region. Students from most of the countries in East Africa were among the first graduates to start professional practices in the region, including those of QSs in Uganda. Anecdotal evidence indicates that the first indigenous QS firm in Uganda was established in 1972.

\subsection{Challenges in Alignment of Education, Training, and Practice of Quantity Surveying}

Although there is a scarcity of literature related to the challenges in the alignment of education, training, and the professional practice of Quantity Surveying, the available research suggests that there are existing mismatches and weak links between educational institutions, professional institutions, and industry practitioners (RICS, 2011; Perera et al., 2011; Wong, Wong, \& Hui, 2007; Bhattacharjee, Ghosh, Young-Corbett, \& Fiori, 2013; Yogeshwaran, Perera, \& Ariyachandra, 2018; Owusu-Manu, Edwards, Holt, \& Prince, 2014). This, therefore, calls for stronger linkages through seminars, workshops, and more avenues for practical skills training between industry practitioners and institutions of higher learning. Existing research also advocates for more on-site training opportunities through regular site visits, work placements, and sandwich training periods before completion of academic programmes.

Despite all the good intentions, with the current global recessions and other economic challenges faced by industry practitioners, the engagement of practitioners in the practical training of students is likely to continue to be low, unless deliberate interventions are put in place by all stakeholders. Another source of mismatch cited in the available literature is the misalignment of expectations of competencies between the academics and the practitioners, where academics are interested in producing a rounded graduate with a basic foundation in knowledge for further development; the industry is looking for a graduate who can contribute immediately both to the daily functions of business and to its growth, and professional institutions/bodies are interested in maintaining professional standards and quality benchmarks (RICS, 2011; Perera et al., 2011). Furthermore, since curricula used for programme delivery tend to continuously get updated, some of the senior industry practitioners may not be aware of the curricula currently being used in Universities, which may result in a mismatch of expectations.

Studies are therefore necessary to provide more insight into the current levels of perceptions and aspirations by Quantity Surveying practitioners in Uganda, to bridge the existing gaps and minimize the current mismatches. This could potentially improve the quality of Quantity Surveying programmes at institutions of higher learning. In addition, this would help set up opportunities for promoting good communication, effective dissemination of information, consultation, and feedback, in order to encourage collaborative developments in teaching and research. This would hopefully produce graduates who are industrially relevant, capable of achieving professional qualifications within reasonable timescales, and with a sound academic background. 


\section{Method}

\subsection{Study Design}

The study population was comprised of 300 (as at April 2020) members under the ISU QS chapter and are practicing in the Ugandan Construction Industry. Contact was made with the ISU to obtain an official list of potential respondents. ISU registers QSs in several categories including Fellows, Professional Members, Associate Members, Graduate Members, Technicians, and Students (ISU, 2020); the focus of the research was on the first four categories of respondents. Sampling was not necessary and as such the entire research population was considered for the study. There was no interest in the study to stratify the sample and as such, responses from across memberships were aggregated.

\subsection{Data Collection}

A semi-structured online questionnaire was designed and administered (April - May 2020) to collect both quantitative and qualitative information (Denscombe, 2010). The questionnaire was composed of both closed and open-ended questions. Close-ended questions were meant to capture factual information from respondents, such as academic qualifications and membership designations from the professional association. A closed-ended question, based on a 5-point Likert scale (Jamieson, 2004), was also included to capture opinions of respondents with regards to the extent they considered the Quantity Surveying program to be relevant. In order to facilitate respondents to have an informed judgement, the existing curriculum was presented in form of summarised course unit descriptions for each of the four years of the program. This was included for respondents to comment on the course units covered, their scheduling and applicability. This was followed by another open-ended question soliciting opinions on what the respondents thought could be done to improve the training curriculum of Quantity Surveying students in order to match the current trends and changes of the industry. The questionnaire was pilot-tested with 10 people, who were QSs in order to ensure validity and reliability of the concepts and questions measured. To allow wider circulation and adequate response rates, the link to the online questionnaire was shared via email and WhatsApp platforms of the respondents. Personal follow-up reminders were also sent in the middle and towards the end of the data collection period, which was limited to two weeks; from $20^{\text {th }}$ April 2020 to $4^{\text {th }}$ May 2020.

\subsection{Data Analysis}

The analysis of the data catered for both quantitative and qualitative data gathered from closed and open-ended questions, respectively. For quantitative data, elementary descriptive statistics were used to analyse the data, and results were presented in form of tables and graphs (Field, 2013). Open-ended questions generated qualitative data that was not amenable to statistical data processing since the output was mostly non-numeric (i.e. words and phrases) and as such, qualitative data analysis techniques were employed. A framework matrix was used to analyse qualitative data. In a framework matrix, qualitative data are summarized in a table of rows and columns in order to allow for both cross-case analyses and sorting data by themes (Bazeley and Jackson, 2013). Respondents were sorted by rows whereas their responses were sorted by columns. The research team read through all the responses in order to generate themes which were equally sorted by columns in the framework matrix. The process of developing themes included "coding", a qualitative data "analytic process through which data are fractured, conceptualised, and integrated ..." (Strauss, 1998). The emerged themes were thus defined as the strategies for improving Quantity Surveyors' education training in Uganda.

\section{Results and discussion}

\subsection{Overview of Survey Responses}

Out of the 300 potential responses, 56 responses were obtained, representing a survey response rate of $19 \%$. Low response rates are not uncommon for web-based surveys and could go as low as $10 \%$ (Mol, 2017). As such, this rate was considered adequate given that it is also comparable to that achieved by Nulty (2008) from a comparison of online response rates obtained by different researchers. Half (50\%) of the respondents were graduate members who are actively practicing QSs, implying that reliable and credible information on how to better the profession was expected (Figure 1). Data about the respondents' educational background is presented in Figure 2, whereby the biggest percentage of the respondents $(67 \%)$ was bachelor's degree holders and the remaining $33 \%$ at Masters Level. None of the respondents indicated to have a Ph.D. Meanwhile, $77 \%$ of the respondents were graduates from the Construction Economics and Management (CEM) department of Makerere University, while the remaining $21 \%$ were from other institutions. Since the majority was graduates from the department, implying they experienced and went through the existing university system and teaching curriculum, they were better placed to advice on how to improve the current system. 


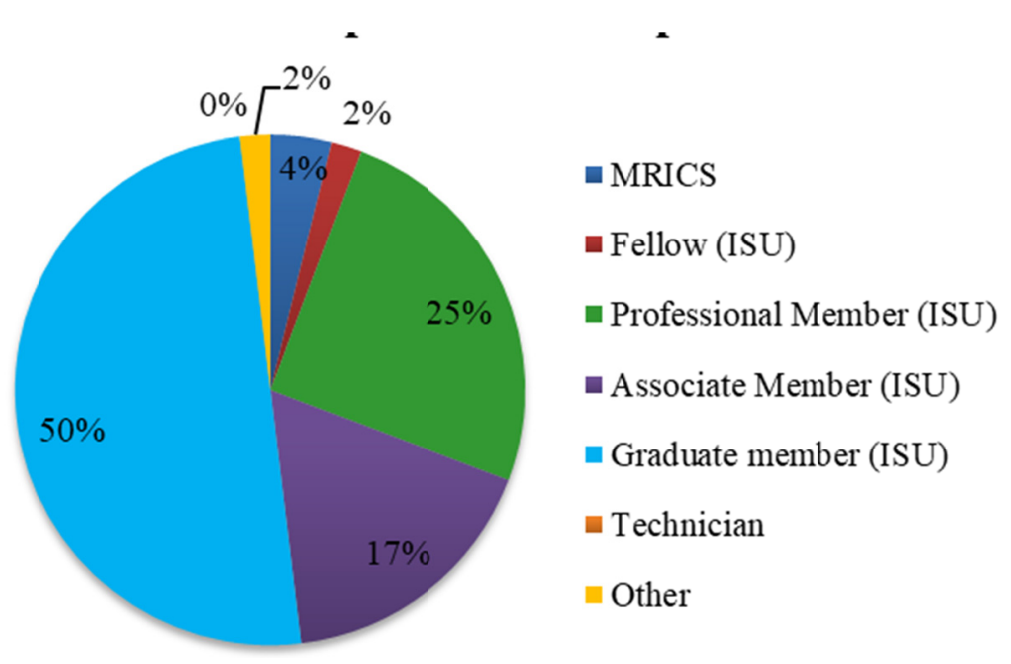

Figure 1. Membership status of respondents

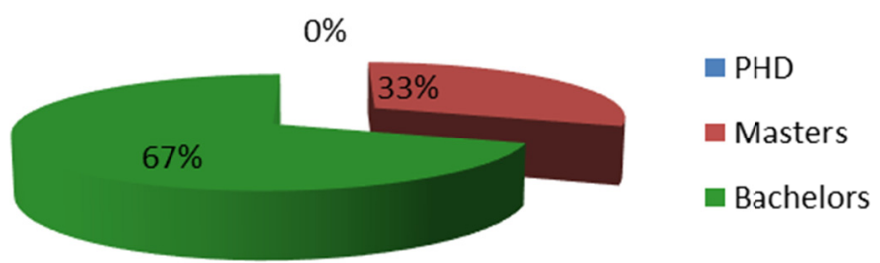

Figure 2. The education level of respondents

\subsection{Relevance of $Q S$}

It was important to assess the extent to which a QS is still relevant amidst the current technology changes in Uganda (see Figure 3). It can be noted that $50 \%$ of the respondents thought that a QS is still relevant in the current construction industry to a very great extent, $37 \%$ to a great extent, $12 \%$ to a moderate extent, and only $2 \%$ to a small extent. None of the respondents thought that the QS was not relevant at all and as such, it can be concluded that even with the current technological advances and trends in the construction industry, the QS is still very relevant, and thus is a key player in the construction industry of Uganda.

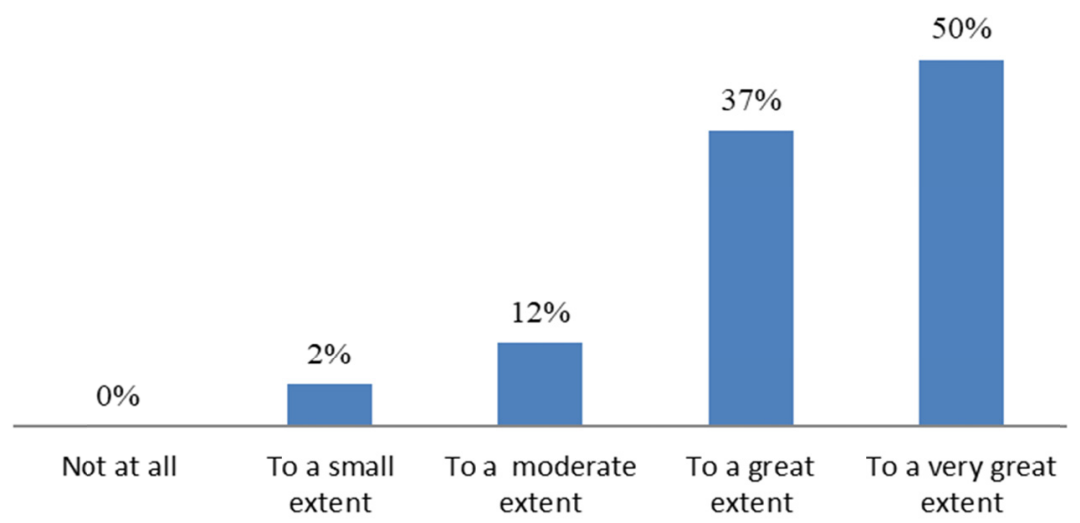

Figure 3. Relevance of Quantity Surveying 


\subsection{Strategies of Improving Quantity Surveying Training}

On review of all the responses given, three main strategies, identified by themes, based on the key players and collaborations required to merge education and the industry were created. These included 1) the university itself, 2) collaboration between the university and students, and 3) collaboration between the university and external bodies (see Figure 4). Under each theme, subthemes were created using a response matrix (see Appendix 1) with the main themes and sub-themes summarized.

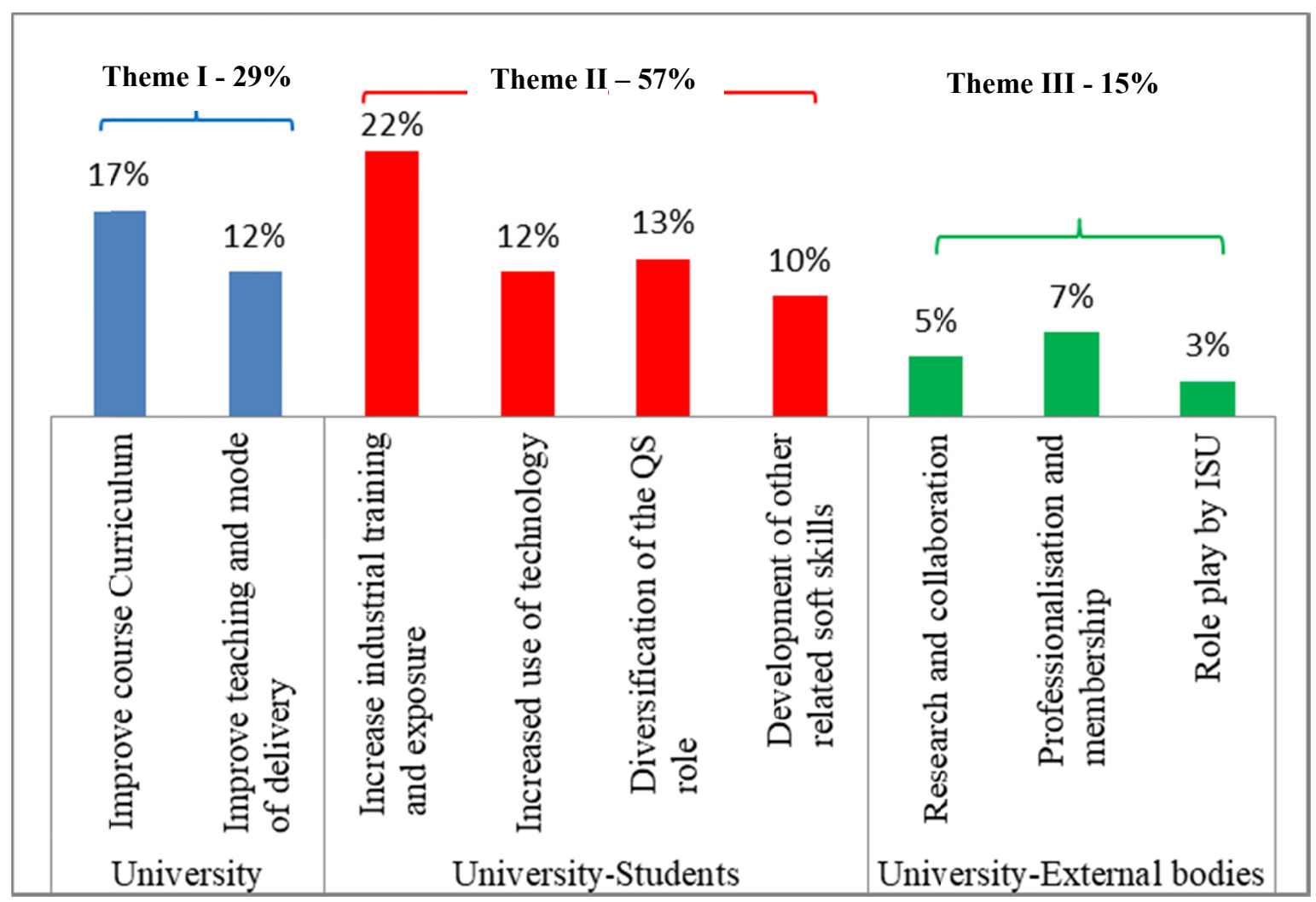

Figure 4. Ways of improving Quantity Surveying training

From Figure 4, recommendations on how to match education and training with industry needs were mainly geared on Theme II - the collaboration between the university and students, taking up about $57 \%$, followed by Theme I action by the university itself with $29 \%$ and lastly Theme III - collaboration between the university and external bodies with $15 \%$. Generally, the top three sub-themes/suggestions included, increasing industrial training and exposure of students to the industry, followed by improvement of the university Quantity Surveying course curriculum, then diversification of the QS role both in the classroom and the field. The three strategies are further explained below.

\subsubsection{University Strategy}

The university was tasked with continuous improvement and creation of a robust Quantity Surveying curriculum that encompasses all the training needs of modern QS to fit in any service sector in Uganda. Majority of the respondents argued that emphasizing major units like construction technology, contract administration, accounting, and Computer Aid Design (CAD), and incorporating new units like procurement and Building Information Modelling (BIM) was imperative. One member suggested that emphasis be put on civil engineering works just as much as building works and in addition, that the accounting module is given extra attention since QSs if equipped with accounting knowledge, can make good accounting officers to construction firms.

In addition to the robust curriculum, improvement in teaching and mode of delivery of the subjects was also deemed necessary. About $90 \%$ of the comments were related to the need for practicality when teaching each course unit, for example by engaging students in more practical exercises, use of case studies with field trips where necessary, and adoption of a problem-solving approach based on prevailing challenges in the industry. One 
respondent focused on the lecturers, suggesting that on top of exhausting each course unit, lecturers need to put in more time and emphasis when teaching areas the students may not be familiar with and be able to teach them well. Another member also insisted that the university needs to employ people who are passionate about imparting knowledge onto the next generation.

\subsubsection{University and Student Strategy}

Under Theme II- collaboration between the university and students, majority of the responses surrounding industrial training and exposure suggested early introduction and exposure of students to real field practice for all four years - in order to boost their knowledge and skills of the profession. These findings are similar to those presented by Kibwami, Mugiraneza, Ndibwami, and Sheja (2020), where industrial training was identified as the largest contributor in preparing QS students in Rwanda to start work. One member further suggested attaching students to a construction site for two years and to a QS firm for the remaining two years. These sentiments reaffirm earlier work, suggesting that learning also happens outside the classroom, and arguing that graduates of the $21^{\text {st }}$ century are indeed "nuanced and hybrid" (Helyer \& Lee, 2014, p. 352). Another respondent suggested that other than just industrial training which could limit the students' exposure depending on where they do it from, fieldwork should be emphasized as it could quicken the students' appreciation and understanding of what they study. In addition, careful training/internship placements, as well as close supervision of students by the university lecturers during training, were emphasized by another professional member.

The technology was also looked at as the way forward for the modern QS. Literature suggests that key Quantity surveying practices, such as cost management, can be greatly enhanced by innovative technological solutions, like use of building product models (Matipa, Kelliher, \& Keane, 2008). Therefore, in order to match the current Information Technology (IT) advancement and professional development in all sectors, respondents put the emphasis on the introduction and use of technology as part of the training. About $80 \%$ of the respondents focused on the introduction and use of software like BIM, Microsoft excel, and other QS software with one member suggesting their application for taking-off and billing as the manual way is becoming outdated.

In terms of diversification of the QS role, one member thought it wise to redefine the QS role and set it apart from others, while all the remaining respondents suggested expansion of this role to cover not only the building sector but also other service sectors of the economy like the oil and gas sector, transport and water resources sectors, energy, mining, manufacturing, process engineering, the banking sector, and others. One Associate Member highlighted the need to change the mindset of both the lecturers and students to focus on more than just construction. Another member suggested carrier talks to open up students' minds to the enormous opportunities in such sectors.

Given the diverse nature of the construction industry, the respondents advised the university to help the students develop other technical skills such as general management skills, business, and people management skills as well as soft skills such as time management, communication, teamwork, and presentation skills. One professional member suggested the need to impart research and innovation skills into students so as to groom them into future researchers and innovators. This was in line with a response from a Graduate member who suggested the need to encourage students to learn to love and pursue knowledge and to think creatively in order to create cost solutions that are unique to Uganda and Africa. The respondent insisted that there was no reason a computer programmer with QS knowledge could not provide QS software that is cheaper than those out there, thus giving them a more competitive edge.

\subsubsection{University and External Stakeholder Strategy}

Previous research has emphasized that linkages between universities and the industry are critical to improvement of surveying education (Wong, Wong, \& Hui, 2007). In the present study, collaboration between the university and external bodies involved roles to be played by the professional bodies, private firms/companies, and government alongside the university itself. The respondents identified the need for industry research and collaboration with all the key players in the construction sector to streamline the training offered and skills imparted for example during industrial training. One Professional Member also noted the need for RICS accreditation of the Quantity Surveying course offered at the university to make it global.

The need for professionalization and institutional membership was also deemed imperative by the respondents. For example, one member suggested mandatory ISU student membership adding that student participation in the institution's activities such as Continuous Professional Developments (CPDs) could increase their chances of interaction with the practicing professionals and enhance learning. A suggestion was also made for the professional institutions (ISU and RICS) to ease registration - as the process was reported to be arduous and badly painted so as to boost the number of QSs joining the field. 
ISU as an institution governing the Quantity Surveying profession was also tasked with lobbying for the interests of QSs especially in government departments and more legal recognition of the Quantity Surveying profession in order to open up more employment opportunities. This could open up avenues for more practical training, which would enhance student skills.

\section{Conclusion}

Education systems of Quantity Surveying often do not recognize the multi-directional needs of the QS, which often leads to graduates whom the industry sees as not fulfilling their requirements. This study investigated the strategies that can be used to improve Quantity Surveying training curriculum, focusing on the perceptions of QSs in the construction industry of Uganda. To a great extent, the Quantity Surveying profession was found to be still relevant in the current construction industry. In order to match the training of QSs with the needs of the industry, there is a need to increase industrial training and exposure of students to field practice; improvement of the university QS course curriculum, and diversification of the QS role both in the classroom and the field.

\section{References}

AIQS. (2012). Competency standards for quantity surveyors construction economists and cost engineers. Sydney, Australia: The Australian Institute of Quantity Surveyors.

Ashworth, A., Hogg, K., \& Higgs, C. (2013). Willis's practice and procedure for the quantity surveyor (13th ed.). Oxford, United Kingdom: John Wiley \& Sons Ltd.

Bazeley, P., \& Jackson, K. (2013). Qualitative data analysis with NVivo (2nd ed.). London: SAGE. https://doi.org/10.5944/empiria.29.2014.13149

Bhattacharjee, S., Ghosh, S., Young-Corbett, D. E., \& Fiori, C. M. (2013). Comparison of industry expectations and student perceptions of knowledge and skills required for construction career success. International Journal of Construction Education and Research, 9(1), 19-38. https://doi.org/10.1080/15578771.2011.647248

Cartlidge, D. (2011). New aspects of quantity surveying practice (3rd ed.). London and New York: Spon Press. https://doi.org/10.4324/9780203851104

Denscombe, M. (2010). The good research guide: For small-scale social research projects. GB: Open University Press.

Field, A. (2013). Discovering statistics using IBM SPSS statistics. Sage.

FIG. (2018). FIG guidance on professional competencies for quantity surveyors/construction economists/cost engineers. Copenhagen, Denmark: International Federation of Surveyors, Publication 71.

Helyer, R., \& Lee, D. (2014). The role of work experience in the future employability of higher education graduates. Higher Education Quarterly, 68(3), 348-372. https://doi.org/10.1111/hequ.12055

ISU. (2020). Institution of Surveyors of Uganda. Retrieved from https://www.surveyorsofuganda.org/About-ISU/17/Membership

Jamieson, S. (2004). Likert scales: How to (ab) use them? Medical education, 38(12), 1217-1218. https://doi.org/10.1111/j.1365-2929.2004.02012.x

Kibwami, N., Mugiraneza, P., Ndibwami, A., \& Sheja, D. (2020). Assessing the Level of Work Preparedness of Final-Year BSc Quantity Surveying Students at University of Rwanda. Journal of Educational and Social Research, 10(5), 253. https://doi.org/10.36941/jesr-2020-0103

Kirkham, R. (2015). Ferry and Brandon's cost planning of buildings (9th ed.). Oxford, United Kingdom: John Wiley \& Sons Ltd.

Kwakye, A. (1997). Construction project administration in practice. Essex, United Kingdom: Pearson Education Limited.

Matipa, W. M., Kelliher, D., \& Keane, M. (2008). How a quantity surveyor can ease cost management at the design stage using a building product model. Construction Innovation, 8(3), 164-181. https://doi.org/10.1108/14714170810888949

Nulty, D. D. (2008). The adequacy of response rates to online and paper surveys: what can be done? Assessment \& evaluation in higher education, 33(3), 301-314. https://doi.org/10.1080/02602930701293231.

Owusu-Manu, D. G., Edwards, D. J., Holt, G. D., \& Prince, C. (2014). Industry and higher education integration: A focus on quantity surveying practice. Industry and Higher Education, 28(1), 27-37. 
https://doi.org/10.5367/ihe.2014.0188

Perera, S. (2006). Views of prospective graduate surveyors on their professional career plans: A survey of the final year undergraduates of the surveying courses conducted by the University of Ulster. RICS, Northern Ireland.

Perera, S., Pearson, J., Robson, S., \& Ekundayo, D. (2011). Alignment of academic and industrial development needs for quantity surveyors: The views of industry and academia.

RICS. (2004). Innovation and current practice in large UK quantity surveying firms. London, United Kingdom: Royal Institution of Chartered Surveyors.

RICS. (2011). Alignment of professional, academic and industrial development needs for quantity surveyors: The post recession dynamics. London, United Kingdom: Royal Institution of Chartered Surveyors.

RICS. (2016a). RICS professional guidance, UK: Commercial management of construction. London, United Kingdom: Royal Institution of Chartered Surveyors.

RICS. (2016b). A comparative study of construction cost and commercial management services in the UK and China. London, United Kingdom: Royal Institution of Chartered Surveyors.

RICS. (2018). RICS requirements and competencies guide. London, United Kingdom: Royal Institution of Chartered Surveyors.

Schumpeter, J. A. (1983). The theory of economic development. New Brunswick, New Jersey: Transaction Publishers.

Seeley, I. H. (1997). Quantity surveying practice (2nd ed.). London, United Kingdom: Macmillan Press Limited. https://doi.org/10.1007/978-1-349-14402-0.

Smith, P. (2015). Professional standards for quantity surveying and cost engineering - global issues and strategies. In Proceedings of the 19th Pacific Association of Quantity Surveyors Congress, Japan, June 2015.

Strauss, A. L., \& Corbin, J. M. (1998). Basics of qualitative research: Techniques and procedures for developing grounded theory (2nd ed.). Thousand Oaks: Sage Publications.

Towey, D. (2012). Construction quantity surveying a practical guide for the contractor's QS. West Sussex, United Kingdom: John Wiley \& Sons Ltd.

Van Mol, C. (2017). Improving web survey efficiency: the impact of an extra reminder and reminder content on web survey response. International Journal of Social Research Methodology, 20(4), 317-327. https://doi.org/10.1080/13645579.2016.1185255

Wong, J. M., Wong, F. K., \& Hui, E. C. (2007). A study to improve higher education for surveying professionals in Hong Kong. Journal for Education in the Built Environment, 2(1), 76-89. https://doi.org/10.11120/jebe.2007.02010076 


\section{Appendix A}

Thematic analysis of responses

\begin{tabular}{|c|c|c|c|c|}
\hline Main Theme & Sub-Themes & Examples of Responses & Freq. & $\%$ \\
\hline \multirow{2}{*}{ Action by the University } & Improve course Curriculum & $\begin{array}{l}\text { Review of the curriculum to suit the current and future } \\
\text { demand is paramount. } \\
\text { Borrow more course units from the field of procurement. } \\
\text { Incorporating new topics into the existing course units or } \\
\text { adding new course units }\end{array}$ & 10 & $17 \%$ \\
\hline & $\begin{array}{l}\text { Improve teaching and mode } \\
\text { of delivery }\end{array}$ & $\begin{array}{l}\text { More practical than theory } \\
\text { Training to be as robust as the course outline. The lecturers } \\
\text { should exhaust each course unit. } \\
\text { Adopting a problem-solving question approach when } \\
\text { teaching }\end{array}$ & 7 & $12 \%$ \\
\hline \multirow{4}{*}{$\begin{array}{l}\text { Collaboration between } \\
\text { University and Students }\end{array}$} & $\begin{array}{l}\text { Increase industrial training } \\
\text { and exposure }\end{array}$ & $\begin{array}{l}\text { Early introduction of students to the field } \\
\text { Generate realistic and tangible learning outcomes for } \\
\text { students while in the field. } \\
\text { Careful internship placements and close supervision by } \\
\text { universities especially during industrial training. }\end{array}$ & 13 & $22 \%$ \\
\hline & Increased use of technology & $\begin{array}{l}\text { Embracing the use of technology } \\
\text { Introduce and incorporate BIM and QS software }\end{array}$ & 7 & $12 \%$ \\
\hline & $\begin{array}{l}\text { Diversification of the QS } \\
\text { role }\end{array}$ & $\begin{array}{l}\text { Redefine the role of a Qs and set it apart from other } \\
\text { professionals } \\
\text { The QS should learn to diversify and look out to providing } \\
\text { services to many sectors of the economy } \\
\text { The services and heavy infrastructure industries need to be } \\
\text { exploited } \\
\text { Change mindset of lecturers and students to more than just } \\
\text { construction }\end{array}$ & 8 & $13 \%$ \\
\hline & $\begin{array}{l}\text { Development of other } \\
\text { related soft skills }\end{array}$ & $\begin{array}{l}\text { Encourage them to develop their soft skills like time } \\
\text { management, communication, teamwork, presentation } \\
\text { skills. } \\
\text { Students need to be imparted with research and innovation } \\
\text { skills. } \\
\text { Equip them with more management skills. }\end{array}$ & 6 & $10 \%$ \\
\hline \multirow{3}{*}{$\begin{array}{l}\text { Collaboration between the } \\
\text { University and external bodies }\end{array}$} & Research and collaboration & $\begin{array}{l}\text { Industry research by Makerere University } \\
\text { University should consider accreditation with RICS to } \\
\text { make this global. } \\
\text { I suggest that the department engages with the industry } \\
\text { players so as to streamline the training offered }\end{array}$ & 3 & $5 \%$ \\
\hline & $\begin{array}{l}\text { Professionalisation } \\
\text { membership }\end{array}$ & $\begin{array}{l}\text { The process of becoming chartered/registered seems } \\
\text { arduous and has been painted in a bad light. } \\
\text { ISU Student Membership should be made mandatory } \\
\text { Encourage CPD attendance by students }\end{array}$ & 4 & $7 \%$ \\
\hline & Roleplay by ISU & $\begin{array}{l}\text { The ISU should be more vibrant in lobbying for QS interest } \\
\text { especially in Government departments. } \\
\text { Lobbying for more legal recognition of the QS profession } \\
\text { in order to open up more employment opportunities. }\end{array}$ & 2 & $3 \%$ \\
\hline
\end{tabular}

\section{Copyrights}

Copyright for this article is retained by the author(s), with first publication rights granted to the journal.

This is an open-access article distributed under the terms and conditions of the Creative Commons Attribution license (http://creativecommons.org/licenses/by/4.0/). 